\title{
Urinary pathogenic bacterial profile, antibiogram of isolates and associated risk factors among diabetic patients in Hawassa town, southern Ethiopia: a cross-sectional study
}

\begin{abstract}
Urinary tract infection (UTI) is the commonest bacterial infectious disease in community practice with a high rate of morbidity and financial cost. It has been estimated that 150 million people were infected with UTI per annum worldwide which costing global economy more than 6 billion US dollar. In humans, urinary tract is the second commonest site after the respiratory tract, for bacterial infection. Two hundreds forty seven diabetic patients were investigated for UTI using 5 to $10 \mathrm{ml}$ midstream urine sample. A loop full urine sample was inoculated on cysteine lactose electrolyte deficient (CLED) agar, MacConkey agar and Blood agar plates. Antimicrobial susceptibility test was done using Clinical and Laboratory Standards Institute (CLSI) for all patients. Age, sex, resident, marital status and other factors were used as exposure factor of the cross sectional study. The aim of this study was to assess etiology, risk factors and drug sensitivity pattern of uropathogenic bacteria isolated from diabetic patients. The overall prevalence of significant bacteriuria was $26(10.5 \%)$. Significant bacteriuria was significantly associated with age and body mass index. The predominant bacteria isolate was E. coli $12(46.2 \%)$ followed by Coagulase negative staphylococcus $7(26.9 \%)$.Gram negative bacteria showed high rate of sensitivity $(94.1 \%)$ to Nitrofurantoin and Norfloxacine. Gram positive bacteria showed $100 \%$ sensitive for Amoxacillin-Clavunic acid. Multidrug resistance to two or more drug was observed in 19(73.1\%) of bacteria isolates. The overall prevalence of significant UTI in diabetic patients was $10.5 \%$. The most frequently observed organisms were $E$. coli, CONS , $K$. pneumoniae, $K$. oxytoca and $S$. aureus. Sex, age, BMI, occupational status such as house wife was statistically significant. Gram negative bacteria isolates were the most common antibiotic resistant bacteria isolates from UTI patients.
\end{abstract}

Keywords: diabetes, UTI, uropathogens, antimicrobial susceptibility
Volume 8 Issue 4 - 2020

\begin{abstract}
Aley Mohammed,' Getnet Beyene,' Lule Teshager,' Deresse Daka

'Jimma University health sciences institute, Jimma Ethiopia

${ }^{2}$ Hawassa University college of Medicine and health sciences, Hawassa Ethiopia
\end{abstract}

Correspondence: Deresse Daka: Hawassa University, College of medicine and heath sciences, Hawassa Ethiopia, Tel +251911968912, Email drsdk20@gmail.com

Received: May 04, 2020 | Published: July 23, 2020
Abbreviations: UTI, urinary tract infection, US, United States, BMI, body mass index; CONs, Coagulase negative Staphylococcus, HUCSH, Hawassa university college of Medicine and health sciences

\section{Introduction}

Urinary tract infection (UTI) is the commonest bacterial infectious disease in community practice with a high rate of morbidity and financial cost. It has been estimated that 150 million people were infected with UTI per annum worldwide which costing global economy more than 6 billion US dollar. ${ }^{1}$ In humans, urinary tract is the second commonest site after the respiratory tract, for bacterial infection. ${ }^{2}$ Many different microorganisms can cause UTIs though the most common pathogens causing are Escherichia coli and other Enterobacteriacae, which accounts approximately $75 \%$ of the isolates. ${ }^{3}$ Gram-positive bacteria such as Enterococcus spp. and Staphylococcus spp. can also cause UTIs. ${ }^{4}$ Over time, patients with diabetes may develop cystopathy, nephropathy, and renal papillary necrosis, complications that predispose them to UTIs. Diabetes mellitus increased risk for UTI. ${ }^{5}$ Higher percentage of resistance to the most commonly prescribed antimicrobial such as Ampicillin, Tetracycline, and Trimethoprimsulphamethoxazole are reported in isolates from diabetic patients. ${ }^{4,6,7}$
History of previous UTI, previous antibiotic treatment, recent sexual behavior, type II diabetes, inadequate glycemic control, and duration of DM have strong association with significant bacteriuria in both symptomatic and asymptomatic diabetic patients. ${ }^{4}$ Since prevalence and type of etiological agent as well as drug susceptibility pattern may vary from time to time or from place to place, it is important to make periodic evaluation that leads to get updated information, however, there is little study conducted on bacterial etiologies, risk factors and antibiotic-resistance patterns in the Southern part of Ethiopia. Therefore this study was undertaken to identify the etiologic agents of UTI, risk factors and their antibiotic resistance patterns among diabetic patients at Hawassa University Referral Hospital, Southern Ethiopia.

\section{Material and methods}

\section{Study design and area}

A cross-sectional study was conducted from March to May 2018 at Hawassa University Referral Hospital, Southern Ethiopia. The hospital is a tertiary level teaching Hospital that provides health services to over six million inhabitants in southern Ethiopia and it is located $275 \mathrm{~km}$ south from the capital city, Addis Ababa. 


\section{Specimen collection and processing}

Five to $10 \mathrm{ml}$ of midstream urine specimen was collected from each diabetic patient and labeled with a unique sample number. The specimens were processed within an hour of collection. ${ }^{8}$

\section{Culturing and identification of isolates}

A loop full of urine was inoculated on cysteine lactose electrolyte deficient (CLED) agar, MacConkey, and Blood agar plates (Oxoid, Ltd., Basingstoke, Hampshire, England) by using a sterile calibrated wire loop with a volume of $0.001 \mathrm{ml}$ after the specimen was mixed. The plates were incubated aerobically at $35-37^{\circ} \mathrm{c}$ for 24 hour and the outcome was judged as significant/ non-significant growth, or contaminated (discarded). Urine culture plates showing $\geq 10^{5}$ colonyforming units $(\mathrm{CFU}) / \mathrm{ml}$ of single bacterial species were considered as significant bacteriuria. ${ }^{9}$ Gram reaction of the organisms, microscopic appearance and colony characteristics were the presumptive identification criteria. Indole production, citrate utilization, $\mathrm{H}_{2} \mathrm{~S}$ production, gas production, urea hydrolysis, lysine decarboxylation, lactose fermentation and motility were used for further identification of gram negative bacteria. Coagulase, catalase, and mannitol fermentation test were used for further identification of gram positive bacteria. $^{8}$

\section{Antimicrobial susceptibility tests}

Antimicrobial susceptibility pattern was performed for all positive isolates using the standardized Kirby Bauer disc diffusion technique according to the criteria of the Clinical and Laboratory Standards Institute (CLSI). ${ }^{10}$ Then Antibiotic impregnated discs Ampicillin



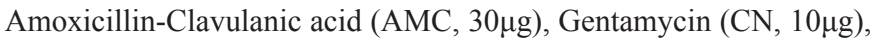
Ceftriaxone $(\mathrm{CRO}, 30 \mu \mathrm{g})$, Nitrofurantoin $(\mathrm{F}, 300 \mu \mathrm{g})$, Norfloxacin

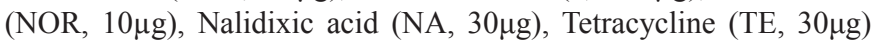
Ciprofloxacin (CIP, 5 $\mu \mathrm{g}$ ) and Penicillin (P, $10 \mathrm{IU}$ ) were placed onto the surface of. Mueller-Hinton agar. Standard strains of E. coli ATCC 25922 and S. aureus ATCC 25923 were used to check the quality of culture and as a control for antimicrobial susceptibility testing.

\section{Data analysis}

Data were cleaned, enter into a computer and statistical analysis were performed by using SPSS v.21 statistical software package. Logistic regression analysis was done to determine the association between independent and dependent variables. All independent variables with a p-value less than or equal to 0.2 in the bivariate analysis were included in the multivariate logistic regression model to identify variables which were associated independently. Odds ratio (OR) within $95 \%$ confident interval (CI) was calculated to measure the strength of association, and $\mathrm{p}$-value $<0.05$ was considered statistically significant. Hosmer-Lemeshow and multi - collinearity tests were done to assess the goodness-of-fit of the model and the presence of collinearity of the variance, respectively.

\section{Results}

\section{Socio- demographic characteristics}

A total of 247 diabetic patients were investigated for UTI. Majority of the participants were male 145 (58.7\%) and the remaining $102(41.3 \%)$ were female with male to female ratio of $1.42: 1$. The mean age of study participants were $45.0 \pm 13.7$ years (range, 1879 years). Majority of study participants were from urban area
192(77.7\%), married $218(88.3 \%)$ and literate $196(79.4 \%)$. The occupational status of a study participants, $82(33.2 \%)$ were merchant and 57(23.1\%) were house wife (Table 1).

Table I Frequency of Socio-demographic variables of diabetic patients diagnosed for UTIs from March- May, 2018 at HUCSH, Hawassa, and South Ethiopia

\begin{tabular}{lll}
\hline Variable & Categories & Frequency
\end{tabular}

Age

$\begin{array}{lll}18-39 & 84 & 34 \\ 40-59 & 118 & 47.8 \\ >=60 & 45 & 18.2\end{array}$

Sex

$\begin{array}{lrr}\text { Male } & 145 & 58.7 \\ \text { Female } & 102 & 41.3\end{array}$

Resident

$\begin{array}{lll}\text { Urban } & 192 & 77.7 \\ \text { Rural } & 55 & 22.3\end{array}$

Marital status

$\begin{array}{lll}\text { Married } & 218 & 88.3 \\ \text { Unmarried* } & 29 & 11.7\end{array}$

Education

$\begin{array}{lll}\text { Illiterate } & 51 & 20.6 \\ \text { Literate }^{* *} & 196 & 79.4\end{array}$

Occupation

$\begin{array}{lcc}\text { Farmer } & 41 & 16.6 \\ \text { Merchant } & 82 & 33.2 \\ \text { House wife } & 57 & 23.1 \\ \text { Civil servant } & 47 & 19 \\ \text { Others*** } & 20 & 8.1\end{array}$

*Single, Divorced, Widowed; **Primary school and above; ***Student, Daily labor

\section{Clinical characteristics}

Among 247 study participants, 198(80.2\%) patients had no symptoms of UTI and the remaining $49(19.8 \%)$ presented with symptoms of UTI. Majority of participants were type II DM $202(81.1 \%)$. Duration of DM less than 5 years observed in $150(60.7 \%)$ of participants. History of previous UTI and catheterization were found in $18(7.3 \%)$ and $7(2.8 \%)$ of study participants, respectively. Body mass index $<25 \mathrm{~kg} / \mathrm{m}^{2}, 25-29.9 \mathrm{~kg} / \mathrm{m}^{2}$ and $>=30 \mathrm{~kg} / \mathrm{m}^{2}$ were found in 147(59.5\%), 81(32.8\%), and 19(7.7\%) of study participants, respectively (Table 2 ). 
Table 2 Frequency of Clinical variables of diabetic patients from March to May, 2018 at HUCSH, Hawassa, South Ethiopia

\begin{tabular}{|c|c|c|c|}
\hline Variable & Categories & Frequency & $\%$ \\
\hline \multicolumn{4}{|c|}{ Symptoms } \\
\hline & Symptomatic & 49 & 19.8 \\
\hline & Asymptomatic & 198 & 80.2 \\
\hline \multicolumn{4}{|c|}{ Type of DM } \\
\hline & Type I & 45 & 18.2 \\
\hline & Type II & 202 & 81.8 \\
\hline \multicolumn{4}{|c|}{ Duration of DM } \\
\hline & $<5$ year & 150 & 60.7 \\
\hline & $>=$ year & 97 & 39.3 \\
\hline \multicolumn{4}{|c|}{ FBS $(m g / d l) *$} \\
\hline & $<126$ & 79 & 32 \\
\hline & $>=126$ & 168 & 68 \\
\hline \multicolumn{4}{|c|}{ Medication for DM } \\
\hline & Tablet & 150 & 60.7 \\
\hline & Insulin & 74 & 30 \\
\hline & Both & 23 & 9.3 \\
\hline \multicolumn{4}{|c|}{ Co-morbidity** } \\
\hline & Yes & 70 & 28.3 \\
\hline & No & 177 & 71.7 \\
\hline \multicolumn{4}{|c|}{ Previous UTI } \\
\hline & Yes & 18 & 7.3 \\
\hline & No & 229 & 92.7 \\
\hline \multicolumn{4}{|c|}{ History of catheterization } \\
\hline & Yes & 7 & 2.8 \\
\hline & No & 240 & 97.2 \\
\hline \multicolumn{4}{|c|}{ BMI $(\mathrm{kg} / \mathrm{m} 2)^{* * * *}$} \\
\hline & $<25$ & 147 & 59.5 \\
\hline & $25-29.9$ & 81 & 32.8 \\
\hline & $>=30$ & 19 & 7.7 \\
\hline
\end{tabular}

*Fasting blood sugar; **Hypertension, Blindness $* * *$ Body mass index

\section{Significant bacteria isolates}

The overall bacterial isolates of the current study was $10.5 \%$. Out of the 26 bacteria isolated from the samples, 18(69.2\%) were from female and the remaining were from male participants. Among the 26 isolate $17(65.4 \%)$ were gram negative bacteria and 9(34.6\%) were gram positive bacteria. Six different bacteria species were isolated from study participants. The predominant bacteria isolates were E. coli 12(46.2\%), Coagulase negative staphylococcus (CONs) 7(26.9\%), S. aureus 2(7.7\%), K. pneumonia $2(7.7 \%)$ and $K$. oxytoca 2(7.7\%) (Figure 1).

\section{Risk factors}

In bivariate logistic regression analysis female sex, age range of 40-59 years, house wife occupation, symptoms of UTI, duration of $\mathrm{DM}>=5$ years, insulin medication, history of previous UTI and BMI $>=30 \mathrm{~kg} / \mathrm{m}^{2}$ were met cutoff criteria of $\mathrm{P}<0.25$ and the candidate variables for multiple logistic regression analysis. In multiple logistic regression analysis the risk variables, age range 40 59 years $(\mathrm{AOR}=0.19 ; 95 \% \mathrm{CI}=0.05-0.65 ; \mathrm{p}<0.01)$ and $\mathrm{BMI}>=30 \mathrm{~kg} /$ $\mathrm{m}^{2}(\mathrm{AOR}=14.44 ; 95 \% \mathrm{CI}=3.55-58.77 ; \mathrm{p}<0.01)$ were found to be statistically significant associated with bacteriuria. Age range of 40- 
59 years were $80 \%$ less likely develop significant bacteriuria than age range of $18-39$ years $(\mathrm{AOR}=0.19 ; 95 \% \mathrm{CI}=0.05-0.65 ; \mathrm{p}<0.01)$. $\mathrm{DM}$ patients with $\mathrm{BMI}>=30 \mathrm{~kg} / \mathrm{m}^{2}(\mathrm{AOR}=11.94 ; 95 \% \mathrm{CI}=3.92-47.30$; $\mathrm{p}<0.01)$ had higher odd ratio compared with those $\mathrm{BMI}<25 \mathrm{~kg} /$ $\mathrm{m}^{2}$. However, sex, occupation, symptoms of UTI, duration of DM, medication for DM and history of previous UTI were not found to be significantly associated with significant bacteriuria $(p>0.05)$ (Table $3)$.

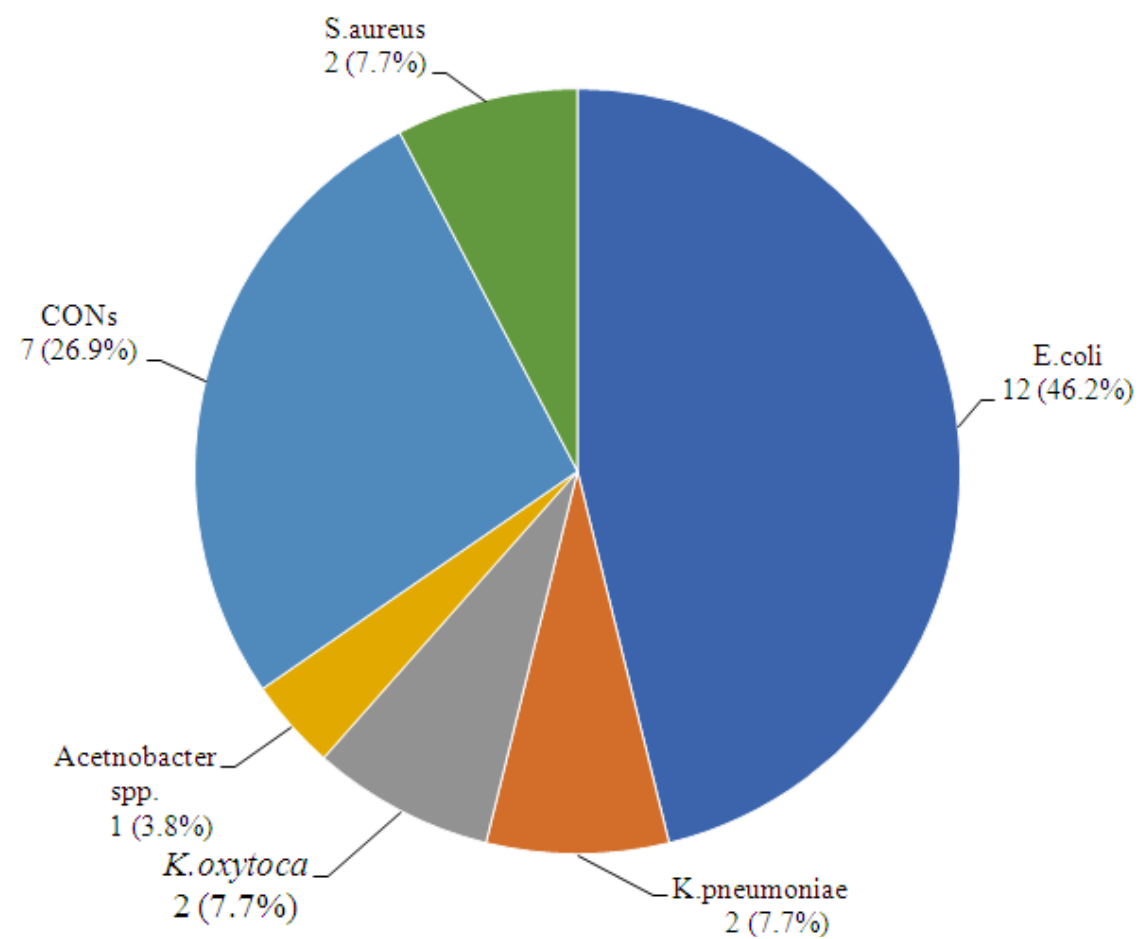

Figure I Distribution of bacteria isolated from diabetic patients from March- May, 2018 at HUCSH, Hawassa, South Ethiopia.

Table 3 Statistical analysis of independent variables with respect to their contribution to significant bacteriuria from March- May, 2018 at HUCSH, Hawassa, South Ethiopia

\begin{tabular}{|c|c|c|c|c|c|c|}
\hline Characteristics & $\begin{array}{l}\text { Significant } \\
\text { bacteriuria }\end{array}$ & $\begin{array}{l}\text { No significant } \\
\text { bacteriuria }\end{array}$ & $\begin{array}{l}\text { COR }(95 \% \mathrm{Cl}) \text { Crude } \\
\text { odds ratio }\end{array}$ & p-value & $\begin{array}{l}\text { AOR }(95 \% \mathrm{Cl}) \text { Adjusted } \\
\text { odds ratio }\end{array}$ & p-value \\
\hline \multicolumn{7}{|l|}{ Age } \\
\hline $18-39$ & $13(15.5)$ & 7I (84.5) & 1 & & I & \\
\hline $40-59$ & $8(6.8)$ & 110 (93.2) & $0.40(0.16-1.01)$ & 0.05 & $0.19(0.05-0.65)$ & $<0.01$ \\
\hline$>=60$ & $5(11.1)$ & $40(88.9)$ & $0.68(0.23-2.06)$ & & $0.72(0.18-2.87)$ & \\
\hline \multicolumn{7}{|l|}{ Sex } \\
\hline Male & $8(5.5)$ & I 37 (94.5) & 1 & & 1 & \\
\hline Female & $18(17.6)$ & $84(82.4)$ & $3.67(\mid .53-8.8 I)$ & 0.03 & $1.54(0.35-6.83)$ & 0.06 \\
\hline \multicolumn{7}{|l|}{ Occupation } \\
\hline Farmer & $2(4.9)$ & $39(95.1)$ & 1 & & I & \\
\hline Merchant & $8(9.8)$ & $74(90.2)$ & $2.1 I(0.43-10.4 I)$ & & I.33 (0.2I-8.42) & \\
\hline House wife & $14(24.6)$ & $43(75.4)$ & $6.35(1.36-29.72)$ & 0.04 & $3.59(0.38-34.12)$ & 0.1 \\
\hline Civil servant & I (2.I) & $46(97.9)$ & $0.42(0.04-4.86)$ & & $0.31(0.02-5.03)$ & \\
\hline Others* & I (5.0) & $19(95.0)$ & $1.03(0.09-12.04)$ & & $0.42(0.03-6.59)$ & \\
\hline \multicolumn{7}{|l|}{ Symptom } \\
\hline Symptomatic & $10(20.4)$ & $39(79.6)$ & $2.92(1.23-6.91)$ & 0.02 & $2.74(0.92-8.13)$ & 0.07 \\
\hline Asymptomatic & $16(8.1)$ & I82 (91.9) & 1 & & 1 & \\
\hline
\end{tabular}


Table Continued.

\begin{tabular}{|c|c|c|c|c|c|c|}
\hline Characteristics & $\begin{array}{l}\text { Significant } \\
\text { bacteriuria }\end{array}$ & $\begin{array}{l}\text { No significant } \\
\text { bacteriuria }\end{array}$ & $\begin{array}{l}\text { COR }(95 \% \mathrm{Cl}) \text { Crude } \\
\text { odds ratio }\end{array}$ & p-value & $\begin{array}{l}\text { AOR }(95 \% \mathrm{Cl}) \text { Adjusted } \\
\text { odds ratio }\end{array}$ & p-value \\
\hline \multicolumn{7}{|l|}{ Duration of DM } \\
\hline$<5$ year & $13(8.7)$ & I 37 (9|.3) & 1 & & $\mathrm{I}$ & \\
\hline$>=5$ year & $13(13.4)$ & $84(86.6)$ & $1.63(0.72-3.69)$ & 0.07 & $\mathrm{I} .30(0.48-3.55)$ & 0.15 \\
\hline \multicolumn{7}{|c|}{ Medication for DM } \\
\hline Tablet & $13(8.7)$ & I 37 (91.3) & 1 & & I & \\
\hline Insulin & $12(16.2)$ & $62(83.8)$ & $2.04(0.88-4.73)$ & 0.23 & $1.93(0.66-5.66)$ & 0.12 \\
\hline Both & I (4.3) & $22(95.7)$ & $0.48(0.60-3.85)$ & & $0.50(0.05-4.6 I)$ & \\
\hline \multicolumn{7}{|c|}{ History of previous UTI } \\
\hline Yes & $4(22.2)$ & I4 (77.8) & $2.69(0.81-8.88)$ & $>0.05$ & $\mathrm{I} .58(0.34-7.46)$ & $>0.05$ \\
\hline No & $22(9.6)$ & $207(90.4)$ & I & & & \\
\hline \multicolumn{7}{|l|}{ BMI $\left(\mathbf{k g} / \mathbf{m}^{2}\right)$} \\
\hline$<25$ & II (7.5) & $136(92.5)$ & $\mathrm{I}$ & & I & \\
\hline $25-29.9$ & $8(9.9)$ & $73(90.1)$ & I.36 (0.52-3.52) & & $2.21(0.70-6.97)$ & \\
\hline$>=30$ & $7(36.8)$ & $12(63.2)$ & 7.21 (2.36-22.03) & $<0.01$ & I4.44 (3.55-58.77) & $<0.01$ \\
\hline
\end{tabular}

*Student, Daily labor; $\mathrm{Cl}$, confidence interval; BMI, body mass index

\section{Antimicrobial susceptibility profile}

Antimicrobial resistance level of Gram negative bacteria isolates were ranged from $5.9 \%$ to $82.4 \%$. From Gram negative bacteria isolates, high rate of resistant (82.4\%) was observed against AMP and TE. On the other hand, high rate of sensitivity $(94.1 \%)$ was observed against $\mathrm{F}$ and NOR. All (100\%) E.coli isolates were sensitive to F and NOR, and $75 \%$ of the isolates (9/12) were sensitive to CRO and CIP. E.coli isolates also showed high resistant to TE 11(91.7\%) and AMP 10(83.3\%). All Klebsella species isolates were sensitive to CN and all of the isolates were found to be resistant to AMP. Single Acetnobacter species isolate was sensitive to AMP, AMC, CRO, F and NOR (Table 4). Antimicrobial resistance level of Gram positive bacteria isolates were ranged from $0 \%$ to $100 \%$. All Gram positive isolates showed resistance against SXT. On the other hand all of isolates were found to be sensitive to AMC. CONs were the predominant gram positive isolate which showed $7(100 \%)$ sensitivity to AMC and $6(85.7 \%)$ sensitive to CRO. On the other hand these bacteria were found to be resistant to SXT (100\%) and TE 6(85.7\%) (Table 5).

\section{Multidrug resistance pattern of the isolates}

Multidrug resistance (resistance to two or more different class of drugs) was observed in $19(73.1 \%)$ of bacterial isolates. Of which $11(57.9 \%)$ and $8(42.1 \%)$ were Gram negative and Gram positive bacteria, respectively. Nine (75.0\%) of the E. coli isolates were MDR Table (6 \& 7).

Table 4 Antimicrobial susceptibility patterns of Gram negative bacteria isolated from diabetic patients with UTI from March- May, 2018 at HUCSH, Hawassa, South Ethiopia

\begin{tabular}{|c|c|c|c|c|c|c|c|c|c|c|c|c|}
\hline Bacteria & Total & S/R & AMP & AMC & SXT & $\mathrm{CN}$ & CRO & $\mathbf{F}$ & NOR & NAL & TE & CIP \\
\hline \multirow[t]{2}{*}{ E.coli } & 12 & S & $2(16.7)$ & $7(58.3)$ & $4(33.3)$ & $7(58.3)$ & $9(75.0)$ & $12(100)$ & $12(100)$ & $3(25.0)$ & $I(8.3)$ & $9(75.0)$ \\
\hline & & $R$ & $10(83.3)$ & $5(4 I .7)$ & $8(66.7)$ & $5(41.7)$ & $3(25.0)$ & $0(0)$ & $0(0)$ & $9(75.0)$ & $11(91.7)$ & $3(25.0)$ \\
\hline \multirow[t]{2}{*}{$\begin{array}{l}\text { K. } \\
\text { pneumoniae }\end{array}$} & 2 & S & $0(0)$ & $I(50.0)$ & $2(100)$ & $2(100)$ & $I(50.0)$ & $I(50.0)$ & $2(100)$ & $I(50.0)$ & $0(0)$ & $2(100)$ \\
\hline & & $\mathrm{R}$ & $2(100)$ & $I(50.0)$ & $0(0)$ & $0(0)$ & $I(50.0)$ & $I(50.0)$ & $0(0)$ & $I(50.0)$ & $2(100)$ & $0(0)$ \\
\hline \multirow[t]{2}{*}{ K. oxytoca } & 2 & S & $0(0)$ & $0(0)$ & $0(0)$ & $2(100)$ & $0(0)$ & $2(100)$ & $I(50.0)$ & $I(50.0)$ & $2(100)$ & $0(0)$ \\
\hline & & $R$ & $2(100)$ & $2(100)$ & $2(100)$ & $0(0)$ & $2(100)$ & $0(0)$ & $I(50.0)$ & $I(50.0)$ & $0(0)$ & $2(100)$ \\
\hline \multirow[t]{2}{*}{$\begin{array}{l}\text { Acetnobacter } \\
\text { spp }\end{array}$} & 1 & $S$ & $I(100)$ & $\mathrm{I}(100)$ & $0(0)$ & $0(0)$ & $I(100)$ & $I(100)$ & $I(100)$ & $0(0)$ & $0(0)$ & $0(0)$ \\
\hline & & $\mathrm{R}$ & $0(0)$ & $0(0)$ & $I(100)$ & $I(100)$ & $0(0)$ & $0(0)$ & $0(0)$ & $I(100)$ & $I(100)$ & $I(100)$ \\
\hline \multirow[t]{2}{*}{ TOTAL } & 17 & S & $3(17.6)$ & $9(52.9)$ & $6(35.3)$ & II(64.7) & II(64.7) & 16(94.I) & $16(94.1)$ & $5(29.4)$ & $3(17.6)$ & II (64.7) \\
\hline & & $\mathrm{R}$ & |4(82.4) & $8(47.1)$ & II(64.7) & $6(35.3)$ & $6(35.3)$ & $\mathrm{I}(5.9)$ & $I(5.9)$ & $12(70.6)$ & $14(82.4)$ & $6(35.3)$ \\
\hline
\end{tabular}

S, sensitive; R, resistance; AMP, ampicillin; AMC, amoxicillin- clavulanic acid; SXT, trimethoprim-sulphamethoxazole; CN, gentamicin; CRO, ceftriaxone; F: nitrofurantoin; NOR, norfloxacine; NAL, nalidixic acid;TE, tetracycline; CIP, ciprofloxacin 
Table 5 Antimicrobial susceptibility patterns of Gram positive bacteria isolated from diabetic patients with UTI from March- May 20 I 8 at HUCSH, Hawassa South Ethiopia

\begin{tabular}{|c|c|c|c|c|c|c|c|c|c|c|c|c|}
\hline Bacteria & Total & $\mathbf{S} / \mathbf{R}$ & AMP & AMC & SXT & $\mathrm{CN}$ & CRO & $\mathbf{F}$ & NOR & TE & CIP & $\mathbf{P}$ \\
\hline \multirow[t]{2}{*}{ CONs } & 7 & $\mathrm{~S}$ & $2(28.6)$ & $7(100)$ & $0(0)$ & $4(57.1)$ & $6(85.7)$ & $4(57.1)$ & $4(57.1)$ & $\mathrm{I}(\mathrm{I} 4.3)$ & $4(57.1)$ & $3(42.9)$ \\
\hline & & $\mathrm{R}$ & $5(71.4)$ & $0(0)$ & $7(100)$ & $3(42.9)$ & $\mathrm{I}(\mathrm{I} 4.3)$ & $3(42.9)$ & $3(42.9)$ & $6(85.7)$ & $3(42.9)$ & $4(57.1)$ \\
\hline S.aureus & 2 & $\mathrm{~S}$ & $0(0)$ & $2(100)$ & $0(0)$ & $2(100)$ & $0(0)$ & $2(100)$ & $I(50.0)$ & $0(0)$ & $\mathrm{I}(50.0)$ & $0(0)$ \\
\hline \multirow[t]{2}{*}{ TOTAL } & 9 & $S$ & $2(22.2)$ & $9(100)$ & $0(0)$ & $6(66.7)$ & $6(66.7)$ & $6(66.7)$ & $5(55.6)$ & $I(I I . I)$ & $5(55.6)$ & $3(33.3)$ \\
\hline & & $\mathrm{R}$ & $7(77.8)$ & $0(0)$ & $9(100)$ & $3(33.3)$ & $3(33.3)$ & $3(33.3)$ & $4(44.4)$ & $8(88.9)$ & $4(44.4)$ & $6(66.7)$ \\
\hline
\end{tabular}

S, sensitive; R, resistance; AMP, ampicillin; AMC, amoxicillin- clavulanic acid; SXT, trimethoprim-sulphamethoxazole; CN, gentamicin; CRO, ceftriaxone; F, nitrofurantoin; NOR, norfloxacine; TE, tetracycline; CIP, ciprofloxacin; P, penicillin; CONs, coagulase negative staphylococcus

Table 6 Multi-drug resistance pattern of Gram negative bacteria isolated from diabetic patients with UTI from March- May 2018 at HUCSH, Hawassa, South Ethiopia

\begin{tabular}{llll}
\hline Antibiotics & E.coli & K.pneumoniae & Total \\
\hline SXT,TE & & & \\
NA,TE & $\mathrm{I}$ & $\mathrm{I}$ & $\mathrm{I}$ \\
AMP,TE & 2 & & 2 \\
AMP,AMC & 2 & 2 \\
AMP,NA,TE & $\mathrm{I}$ & $\mathrm{I}$ \\
AMP,SXT,TE & $\mathrm{I}$ & $\mathrm{I}$ \\
AMP,SXT,TE,CN & $\mathrm{I}$ & & $\mathrm{I}$ \\
AMP,SXT,CRO,AMC,NA & & $\mathrm{I}$ & $\mathrm{I}$ \\
AMP,SXT,AMC,NA,CIP,P & $\mathrm{I}$ & & $\mathrm{I}$ \\
Total & $9(8 I .8 \%)$ & $2(18.2 \%)$ & $\mathrm{I}(100 \%)$ \\
\hline
\end{tabular}

AMP, ampicillin;AMC, amoxicillin- clavulanic acid; SXT, trimethoprim-sulphamethoxazole; CN, gentamicin; CRO, ceftriaxone; F, nitrofurantoin; NOR, norfloxacine; NAL, nalidixic acid; TE, tetracycline; CIP, ciprofloxacin

Table 7 Multi-drug resistance pattern of Gram positive bacteria isolated from diabetic patients with UTI from March- May 2018 at HUCSH, Hawassa, South Ethiopia

\begin{tabular}{llll}
\hline Antibiotics & CONs & S.aureus & Total \\
\hline CIP,NOR & $\mathrm{I}$ & $\mathrm{I}$ \\
SXT,NOR & $\mathrm{I}$ & $\mathrm{I}$ \\
SXT,CIP,P & $\mathrm{I}$ & $\mathrm{I}$ \\
AMP,SXT,P & $\mathrm{I}$ & $\mathrm{I}$ \\
AMP,SXT,TE,CIP & $\mathrm{I}$ & $\mathrm{I}$ \\
AMP,SXT,TE,P & & $\mathrm{I}$ \\
AMP,SXT,TE,P,CRO & $\mathrm{I}$ & $\mathrm{I}$ \\
AMP,SXT,TE,NOR,CIP & & $\mathrm{I}$ & $\mathrm{I}$ \\
Total & & $2(25 \%)$ & $8(\mathrm{I00} \%)$ \\
\hline
\end{tabular}

AMP: ampicillin; AMC: amoxicillin- clavulanic acid; SXT: trimethoprimsulphamethoxazole; $\mathrm{CN}$ : gentamicin; $\mathrm{CRO}$ : ceftriaxone; F: nitrofurantoin; NOR: norfloxacine;TE: tetracycline; CIP: ciprofloxacin; P: penicillin; CONs: coagulase negative Staphylococcus

\section{Discussion}

Urinary tract infection is the commonest bacterial infectious disease with a high rate of morbidity and financial cost. The risk of developing infection in diabetes is higher due to abnormalities in the host defense and high glucose in urine. ${ }^{11}$ In the present study the overall prevalence of significant bacteriuria in diabetic patients was $10.5 \%$. This is similar to the findings reported previously in Addis Ababa (10.9\%), ${ }^{6}$ Debre Tabor $(10.9 \%)^{12}$ and Romania $(10.7 \%),{ }^{13}$ but lower than a study done in Gondar $(17.8 \%)^{4}$ and other studies done in Sudan (19.5\%), ${ }^{7}$ Nepal (21\%) ${ }^{14}$ Iraq $(35.3 \%),{ }^{15}$ and Pakistan $(51 \%) .{ }^{16}$ This variation in prevalence might be due to the difference in sample size, geographical location, personal hygiene, and variation in the screening test used. In our study the most frequently isolated bacterial uropathogens were $E$. coli $12(46.2 \%)$, CONs 7(26.9\%), $K$. pneumoniae $2(7.7 \%)$, K. oxytoca $2(7.7 \%)$ and $S$. aureus $2(7.7 \%)$. The predominant bacteria isolate in our study was $E$. coli. This is similar with previous study finding in Ethiopia (31.7\%) and other countries in Sudan $(56.4 \%)$, Nigeria (46\%), and Cameroon (48\%). ${ }^{4,7,17,18} E$. coli considered the most predominant uropthogen due to a number of virulence factors specific for colonization and invasion of the urinary epithelium. ${ }^{19,20}$ The second most common isolate was CONs $(26.9 \%)$ which is similar with a study done in Gondar $(22.0 \%) .{ }^{4}$ In other hand it is contradicting with a study done in Addis Ababa $28 \%,{ }^{6}$ 
Sudan (23\%), Uganda (28.6\%), India (20\%), Iraq (15.1\%) and Nepal $(21.6 \%))^{7,11,15,21,22}$ The higher isolation rate of CONs in this study could be change in pattern of infection in diabetic patients. ${ }^{11}$

In the present study BMI $>=30 \mathrm{~kg} / \mathrm{m}^{2}$ was 14 times more likely to develop significant bacteriuria $(\mathrm{AOR}=14.44 ; 95 \% \mathrm{CI}=3.55-58.77$; $\mathrm{p}<0.01)$. This is in agreement with a study done in Saudi Arabia ${ }^{23}$ and Spain. ${ }^{24}$ But it disagree with study result in Iran where BMI and UTI showed no association. ${ }^{25}$ In our study age range with 40-59 years were $80 \%$ less likely to develop significant bacteriuria compared with age range of $18-39$ years $(\mathrm{AOR}=0.19 ; 95 \% \mathrm{CI}=0.05-0.65 ; \mathrm{p}<0.01)$. A study in Gondar also showed $30.7 \%$ of bacteriuria within $20-35$ age range, but not statistically significant. ${ }^{4}$ Other studies in Sudan, ${ }^{7}$ and Saudi $\mathrm{Arabia}^{23}$ reported that no significant association between age and significant bacteriuria. The variation may be due to the difference in distribution and categories of age. From our study significant bacteriuria was high among female diabetic patients $(17.6 \%)$ than male diabetic patients $(5.5 \%)$. This is in agreement with many other studies done in Gondar, Ethiopia (21.2\%), Debre Tabor, Ethiopia (16.3\%), Uganda (16.4\%), and Romania (15.3\%), ${ }^{4,12,13,21}$ but contradict with a study done in Sudan which is higher prevalence in male $(21.2 \%)$ than female $(14 \%))^{7}$ This could be due to short urethra, close proximity of the urethra to the anus, sexual activity, decrease of normal vagina flora, less acidic $\mathrm{pH}$ of vaginal surface, lack of prostate secretion, and poor hygienic condition may access entry of bacteria in to bladder and cause infection. ${ }^{4,11}$

In our study the frequency of UTI was higher among duration of DM greater than 5 years $(13.4 \%)$ compared to those duration of DM less than 5 years $(8.7 \%)$, although not statistically significant ( $>0.05)$. This is in agreement with a study done in Gondar, ${ }^{4}$ Sudan, ${ }^{7}$ Saudi Arabia ${ }^{23}$ and $\operatorname{Iran}^{26}$ and disagree with a study done in Romania where longer duration is a significant risk factor associated with UTI. ${ }^{27}$ Duration of diabetes had been described as risk factor for complicated UTI, probably because of concurrent neuropathy. ${ }^{23}$ Over all resistant patterns of gram negative bacteria isolates from DM patients with UTI were AMC 14(82.4\%), TE 14(82.4), NAL $12(70.0 \%)$ and SXT 11(64.7\%). However, 6(35.3\%) resistant pattern was seen on CIP, CRO and CN. Moreover, antibiotic resistant pattern of gram positive bacteria among diabetic UTI patients were SXT $9(100 \%)$, TE $8(88.8 \%)$, AMP $7(77.7 \%)$ and $6(66.6 \%)$. However, $3(33.3 \%)-4(44.4 \%)$ resistant pattern was seen in CN, CRO, F, NOR, and CIP. This is similar with the report of different studies carried on the world. ${ }^{4,7,11,21,28}$ Multidrug resistance was observed in $73.1 \%$ of uropathogenic Bacteria. About 9(81.8\%) gram negative bacteria were multidrug resistant among diabetic UTI patients. Also 6(75\%) of gram positive bacteria was developed multidrug resistant., $4,6,12$ Reason for multidrug resistance of the isolate might be inappropriate and incorrect administration of antimicrobial agents as empirical treatment.

\section{Conclusion}

The overall prevalence of significant UTI in diabetic patients was $10.5 \%$. The most frequently observed organisms were E. coli, CONs, K. pneumoniae, K. oxytoca and S. aureus. Sex, age, BMI, occupational status such as house wife was statistically significant. Gram negative bacteria isolates were the most common antibiotic resistant bacteria isolates from UTI patients.

\section{Acknowledgments}

We would like to acknowledge Jimma University and Hawassa University for their support. Moreover, we appreciate the study participant for their good willing.

\section{Conflicts of interest}

No conflict of interest was declared by the authors.

\section{Funding}

This study was supported by Jimma University and Hawassa University College of Medicine and Health Sciences, The support included payment for data collectors and purchase of materials and supplies required for the study. The support did not include designing of the study, analysis, and interpretation of data, and manuscript preparation and publication.

\section{References}

1. Prakash D, Saxena R. Distribution and Antimicrobial Susceptibility Pattern of Bacterial Pathogens Causing Urinary Tract Infection in Urban Community of Meerut City, India. ISRN Microbiology. 2013;2013:1-13.

2. Pargavi, Mekala T, Selvi A, et al. Prevalence of Urinary Tract Infection among Diabetics patients in Vandavasi, Tamil Nadu, India. International Journal of Biological Technology. 2011;2(2):42-45.

3. Beyene G, Tsegaye W. Bacterial uropathogens in Urinary tract infection and antibiotic susceptibility pattern in Jimma University specialized hospital, South west Ethiopia Ethiop J Health Sci. 2011 21(2):141-146.

4. Yismaw G, Asrat D, Woldeamanuel Y, et al. Urinary Tract Infection: Bacterial etiologies, drugresistance profile and associated risk factors in diabetic patients attending Gondar University Hospital, Gondar, Ethiopia European Journal of Experimental Biology. 2012;2(4):889-898.

5. Jha P, Baral R, Khanal B. Prevalence of Uropathogens in Diabetic Patients and Their Susceptibility Pattern at a Tertiary Care Center in Nepal-A Retrospective Study. IJBLS. 2014;3(2):9-34.

6. Yeshitela B, Gebre-Selassie S, Feleke Y. Asymptomatic bacteriuria and symptomatic urinary tract infections in patients with diabetes mellitus in Tikur Anbessa Specialized University Hospital, Addis Ababa, Ethiopia. Ethiop Med J. 2012;50(3):239-249.

7. Hamdan H, Kubbara E, Adam A, et al. Urinary tract infections and antimicrobial sensitivity among diabetic patients at Khartoum, Sudan. Annal Clini Microbiol Antimicrob. 2015;14(26):1-6.

8. Cheesbrough M. District Laboratory Practice in Tropical Countries. New York: Cambridge University Press. 2006.

9. Pezzlo M. Laboratory Diagnosis of Urinary Tract Infections: Guidelines, Challenges, and Innovations. CMN. 2014;36(12):87-93.

10. CLSI. Performance standards for antimicrobial disk susceptibility testing. Twenty sixth CLSI supplements M100S Wayne, PA: Clinical and Laboratory Standard Institute. 2016.

11. Senthamarai S, Sivasankari S, Anitha C. A study on clinical presentation, bacterial profile and its antibiotic sensitivity pattern in urinary tract infections among diabetic patients attending tertiary care hospital, Tamilnadu. Int J App Res. 2016;2(3):157-159.

12. Worku S, Derbie A, Sinishaw M, et al. Prevalence of Bacteriuria and Antimicrobial Susceptibility Patterns among Diabetic and Nondiabetic Patients Attending at Debre Tabor Hospital, Northwest Ethiopia. International Journal of Microbiology. 2017:1-8.

13. Chita T, Licker M, Sima A, et al. Prevalence of urinary tract infections in diabetic patients. Rom J Diabetes Nutr Metab Dis. 2013;20(2):099-105.

14. Simkhada R. Urinary tract infection and antibiotic sensitivity pattern among diabetics. Nepal Med Coll J. 2013;15(1):1-4.

15. Ahmed A. Prevalence of urinary tract infection in diabetic patients and identification of the causal microorganisms. Zanco J Med Sci. 2013;17(1):363-369. 
16. Ijaz M, Ali S, Khan S. Urinary tract infection in diabetic patients; Causative bacteria and antibiotic sensitivity. J Med Sci. 2014;22(3):110-114.

17. Adeyeba O, Adesiji Y, Omosigho P. Bacterial Urinary Tract Infections in patients with Diabetes Mellitus. Int J Trop Med. 2007;2(3):89-92.

18. Njunda A, Assob N, Nsagha S. Uropathogens from diabetic patients with asymptomatic bacteriuria and Urinary tract infections. Scientific Journal of Microbiology. 2012;1(6):141-146.

19. Alemu A, Moges F, Shiferaw Y, et al. Bacterial profile and drug susceptibility pattern of urinary tract infection in pregnant women at University of Gondar Teaching Hospital, Northwest Ethiopia. BMC Research Notes. 2012;5(197):1-7.

20. Nongrum S, Thaledi S, Singh V, et al. Association of Uropathogens with Asymptomatic Urinary Tract Infection in Diabetes Mellitus Patients. Int J Curr Microbiol App Sci. 2016;5(10):355-361.

21. Ampaire L, Butoto A, Orikiriza P, et al. Bacterial and Drug Susceptibility Profiles of Urinary Tract Infection in Diabetes Mellitus Patients at Mbarara Regional Referral Hospital, Uganda BMRJ. 2015;9(4):1-5.

22. Yadav K, Prakash S. Antimicrobial Resistance Pattern of Uropathogen Causing Urinary Tract Infection (UTI) Among Diabetics Biomed Res Int. 2016;1:07-15.
23. Al-Rubeaan K, Moharram O, Al-Naqeb D, et al. Prevalence of urinary tract infection and risk factors among Saudi patients with diabetes. World J Urol. 2013;31:573-578.

24. Ribera M, Pascual R, Orozco D. Incidence and risk factors associated with urinary tract infection in diabetic patients with and without asymptomatic bacteriuria. Eur J Clin Microbiol Infect Dis. 2006;25:389-393.

25. Nassaji M, Ghorbani R, Tamadon M, et al. Association Between Body Mass Index and Urinary Tract Infection in Adult Patients. Nephro Urol Mon. 2015;7(1):1-4.

26. Raoofi A, Ghavami M, Shahhamzeh M, et al. The Impact of Demographic Factors and Blood Sugar Control on the Incidence of Urinary Tract Infections in Khorramabad in 2013. Iran Red Crescent Med J. 2016;18(5):1-6.

27. Chita T, Timar B, Muntean D, et al. Urinary tract infections in Romanian patients with diabetes: prevalence, etiology, and risk factors. Therapeutics and Clinical Risk Management. 2017;13:1-7.

28. Al-Qaseer A, Abdul-wahab B, Abbas O. Bacteriological finding of urinary tract infection in diabetic patients. Int J Adv Res. 2014;2(10):274-279. 